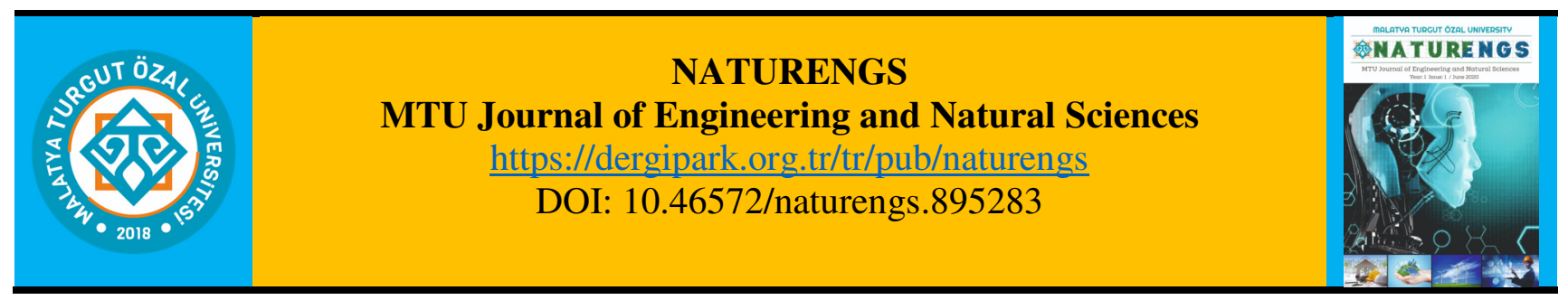

Research Article

\title{
Non-linear and Equivalent Linear Site Response Analysis of Istanbul Soils
}

\author{
Özgür YILDIZ \\ Department of Civil Engineering, Faculty of Engineering and Natural Sciences, \\ Malatya Turgut Özal University, Malatya, Turkey
}

(Received: 11.03.2021; Accepted: 21.05.2021)

\begin{abstract}
The effect of local soil characteristics on the propagation of earthquake waves has been commonly studied by researchers. However, the validity of the results obtained by these studies is limited only to the relevant soil conditions. The main purpose of this study is to examine the effect of soil conditions on the propagation of seismic waves in Istanbul. In this regard, soil information belonging to different districts of Istanbul has been compiled. The site response analysis was simulated using a time-domain non-linear response analysis based on the effective stress method and frequency-domain equivalent linear analysis based on the total stress method. A widely used one-dimensional response analysis program DEEPSOIL was used to estimate the soil response of the sites. Modeled soil profiles were subjected to 1999 Kocaeli earthquake motion and the results of the analysis are presented as spectral acceleration, PGA and lateral displacements. The results obtained from both of the analyses were evaluated comparatively in terms of the effect of soil properties on the propagation of the seismic waves. The effect of the analysis method based on different approaches on the results is examined. Substantial findings have been revealed regarding how the propagation of the earthquake waves is affected by local soil conditions. The liquefaction potential of soil profiles was also evaluated using the data of the soil properties of the investigation area.
\end{abstract}

Keywords: Site response, Equivalent linear analysis, Non-linear analysis, Deepsoil, Earthquake.

\section{INTRODUCTION}

The Mw 7.4 earthquake that occurred in Kocaeli/Gölcük on August 17th 1999, was felt throughout the Marmara region and in a wide area from Ankara to Izmir. Due to the destruction, the loss of life, and the injuries it caused, considerable socio-economic consequences have occurred. Considering the ongoing seismic activities and the earthquake history of the region, it is thought that a possible high-magnitude earthquake that will affect Istanbul may cause significant losses. Although it is approximately $150 \mathrm{~km}$ away from the epicenter of the earthquake, the destruction that occurred after the 1999 Kocaeli earthquake in Avcılar district is attributed to the effect of site conditions on earthquake waves as much as the low constructional quality of the building stock. This brought to mind the term of 'site effect' used in literature after the 1985 Michoacan earthquake caused significant destruction in Mexico City, despite being $435 \mathrm{~km}$ away from the epicenter. The only reason for this is the increase in the displacement of the buildings as a result of the coincidence of the natural vibration periods of the buildings with the dominant periods of the earthquake waves formed on the soft soil surface. Likewise, no building damage occurred in Bursa city center, 135 kilometers away from the epicenter of the 28th March 1970 Gediz Earthquake $(M=7.1)$ but the collapse of the atelier buildings of a factory in the Bursa plain is explained by the enlargement of the seismic wave amplitudes due to layered soft soils [1]. 
The effect of the earthquake at a location depends on many factors such as the magnitude of the earthquake, the distance from the epicenter, duration of ground motion, the geological environment the wave propagated through, the frequency content and the soil conditions in the region. Within all these parameters, the site effect has become an important concern of geotechnical earthquake engineering. It leads to changes in the characteristics of the motion due to the propagation of seismic waves in soil deposits and as a result, has a great impact on the response of structures during earthquake events [2]. In cases the soil profile is single-layered, it is less complex to examine the local soil effect on the propagation of seismic waves compared to stratified soil environments. However, in cases where the soil profile is stratified, relative density, stiffness, thickness, shear wave velocity, damping ratio, and other physical properties of the soil layers and certainly the intensity of the propagating earthquake waves have become important parameters that primarily affect soil behavior. In addition to the effect of soil conditions on seismic waves, soil layers exposed to strong ground motion lose their strength and behave as a viscous liquid that cannot be ignored (such as liquefiable soils). This is known as 'liquefaction' in the literature and is not itself an event that causes structural damage. However, the excessive displacements and settlements due to liquefaction cause foundation failures resulting in great damages.

The effects of soil conditions on the propagation of earthquake waves are measured using site response analysis. These analyzes are performed in two categories; i. linear and equivalent linear analysis in the frequency domain and ii. linear and non-linear analysis in the time domain [2]. In the first studies in this field, the behavior of the soil under dynamic loading was investigated by frequency-domain equivalent linear analysis [3,4]. Later, a software program, SHAKE, was developed by researchers to analyze the seismic site response [5]. A number of modifications have been applied to this program to better reflect the soil behavior [4]. Empirical equations have been developed to analyze the effect of soil properties on propagating seismic waves [6]. Subsequently, both the design response spectra [7] and the effect of different parameters on site response analysis were examined by the researchers [8,9]. Also, successful analyses were performed on locations having high liquefaction potential in Turkey $[10,11]$.

The main purpose of this study is to perform a one-dimensional site response analysis of soils from different districts of Istanbul by using two different methods: i. the equivalent linear method based on total stress modeling in the frequency domain, ii. the non-linear method based on effective stress modeling in the time domain. It is aimed to investigate the effect of soil formations in Istanbul, where rock formations such as limestone or sandstone (i.e. greywacke) with different degrees of weathering are mostly existed, on earthquake waves. In accordance with this purpose, locations with different soil characteristics in the Anatolian and European sides of Istanbul have been selected. Soil profiles of the selected cases were modeled using DEEPSOIL 1D site response analysis program. The non-linear (NLA) and equivalent linear (ELA) analyses were performed with developed soil models. By evaluating the results obtained by both approaches comparatively, substantial findings have been drawn regarding the effects of the local site conditions on the propagation of seismic waves. Evaluations were made on the liquefaction potential of both investigation areas according to commonly used criteria.

\section{GEOLOGICAL STRUCTURE}

Paleozoic formations with a thickness of 2000 meters are found in Istanbul and its surroundings. The upper parts of these formations are made up of Carboniferous aged sandstone (greywacke), siltstone, and claystone, which are called as Trakya formation. On the Paleozoic sequence, there 
are Eocene white-colored, hard fractured limestones with intercalations of marl and carbonated sandstone. The younger sediments with Neogene age exist on top of Eocene units. From the bottom to the top, there are extremely consolidated clay (Gürpınar Formation, Tdg), gravely silty sand (Çukurçeşme Formation), organic clay (Güngören Formation), marl and limestone (Bakırköy Formation) and gravely sandy clay layers (Samandıra Formation). Due to confusion in the field applications and geological maps, the Gürpınar, Çukurçeşme and Güngören formations were collectively named as 'Avcilar Formation' and mapped as a single unit (Figure 1) [12].

The geological structure of Istanbul and its surroundings, whose general stratigraphy is summarized above, consists of formations with lithologies that can frequently change from bottom to top with the erosion of the region. Arkoz and quartzites, which are the oldest units in the visible base, have a very hard rock appearance and sometimes completely sand content. The greywackes known as the Trakya formation, which are encountered in a wider area of Istanbul, are mostly weathered on the surface and cracked up to 15 to 20 meters in thickness at lower depths, and weathered, bluish-gray colored, less weathered units at the bottom. Gürpinar, Çukurçeşme, Güngören, and Bakırköy formations are existing on top of the Eocene limestones, which are located on the graywacke units of the Trakya formation. At the top of these formations, there are gravelly, sandy, silty, clayey alluvial units (Figure 2).

\section{RESPONSE ANALYSIS}

1D site response analysis is used to investigate the effect of local soil conditions on the propagation of seismic waves. Throughout these analyzes, different approaches are used by researchers. These analyzes are applied by using linear, equivalent linear, and non-linear methods. Among these methods, the linear analysis method is performed in the frequency and time domain, the equivalent linear analysis method in the frequency domain, and the non-linear analysis method in the time domain. Linear and equivalent linear analyses are based on the independence of the damping and shear modulus from shear strain, while non-linear analysis is strain-dependent. The soil response with generated excess pore water pressure in time domain analysis is completely different from frequency domain analysis which is a total stress analysis. The excess pore water pressure generated in the site due to a seismic motion have a significant effect on soil behavior by leading to degradation in stiffness. Therefore the soil response obtained using the equivalent linear method does not fully capture the soil behavior. However, as a simple and less number of input variables requiring method, it is suggested to perform equivalent linear analysis in parallel to non-linear analysis especially for soft and having high liquefaction potential soils. In this study, the effects of local soil conditions on wave propagation were comparatively investigated using non-linear and equivalent linear analysis methods. The liquefaction potential of the soil profiles is also examined by using soil properties. 


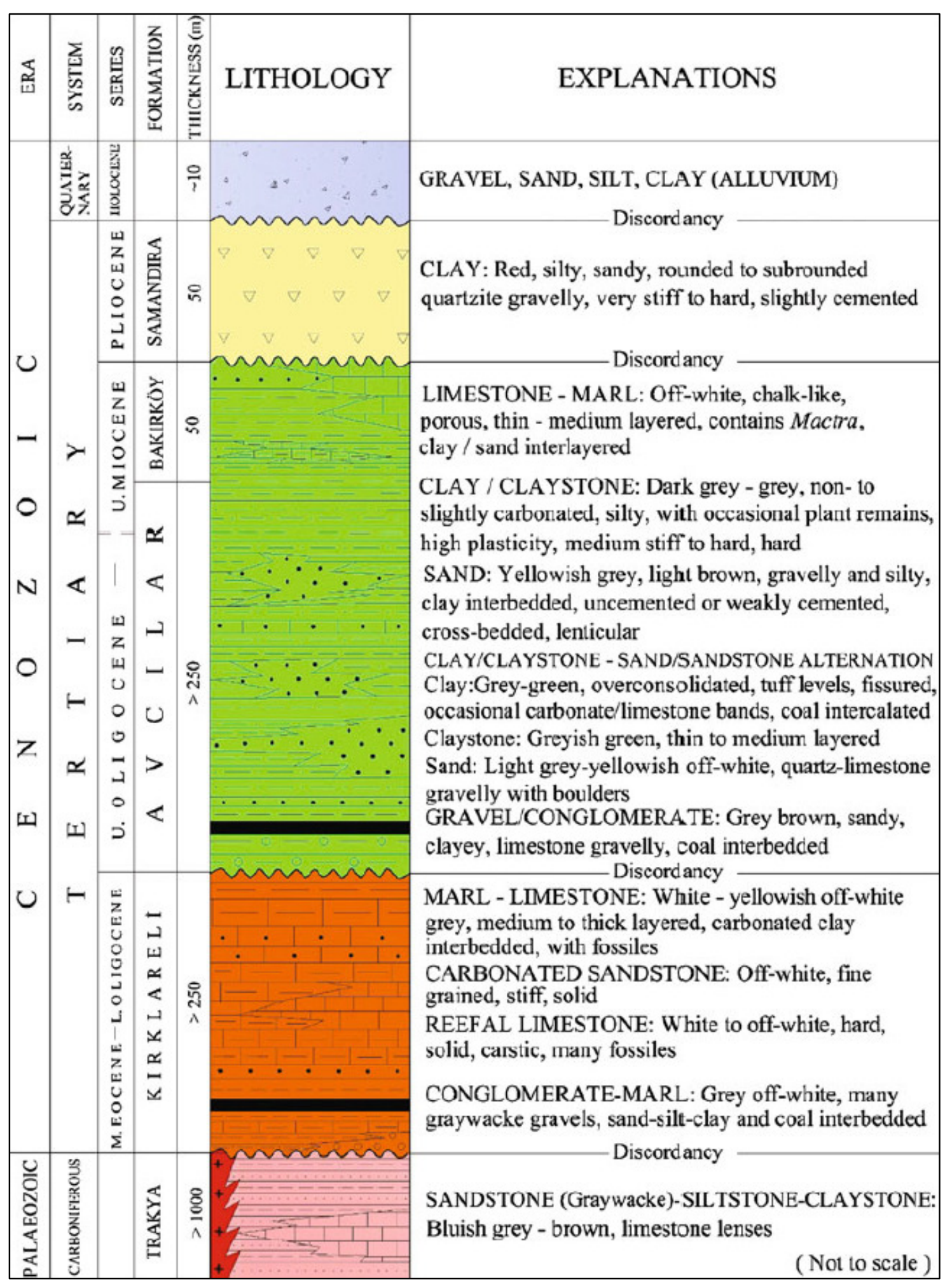

Figure 1. Revised stratigraphy of Istanbul [12] 


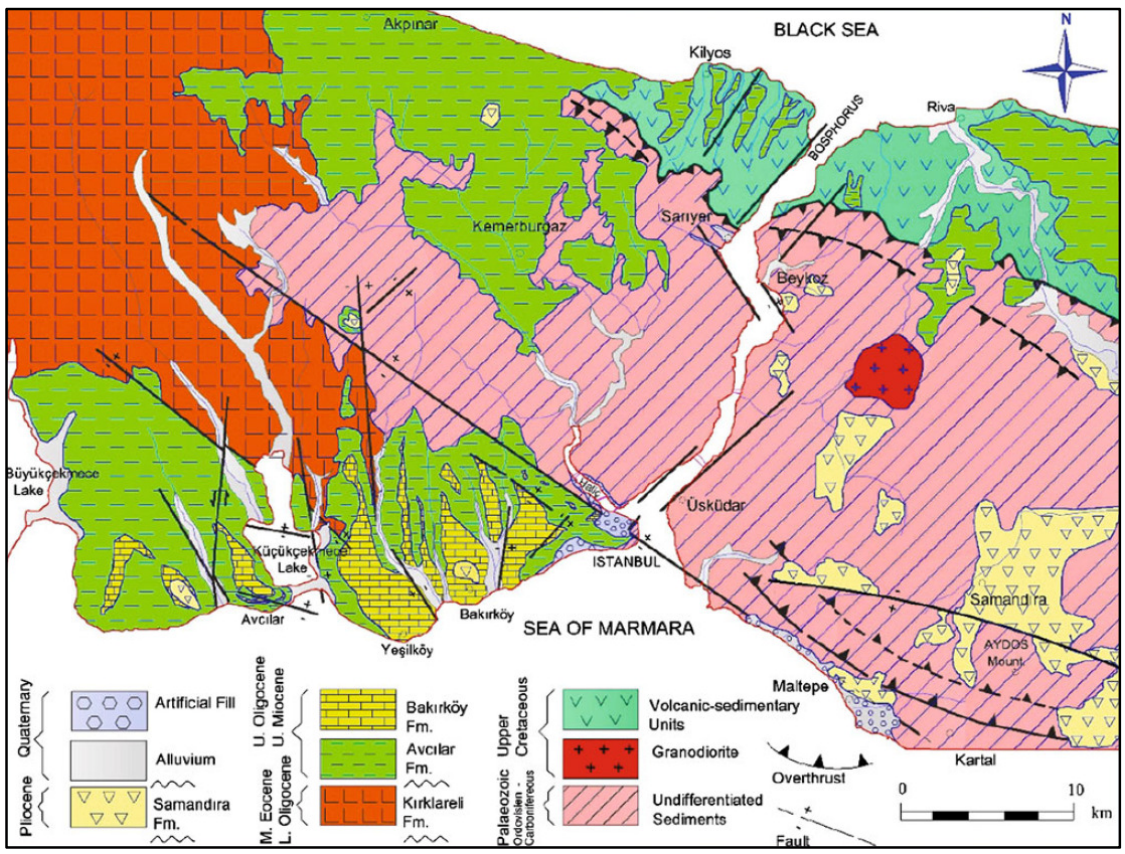

Figure 2. General geological map of Istanbul and its surrounding area [12]

\section{MATERIALS AND METHODS}

The borehole logs obtained by private soil investigation company a total of 4 boreholes, 2 on the Anatolian side (Şile and Pendik district) and 2 on the European side (Avcrlar and Beylikdüzü district) were numerically modeled. The first case from the Anatolian side of Istanbul belongs to the field investigation of single-span bridge construction in the Şile district. The second borehole log has taken from a field study of the construction of an educational institution in Avcrlar district. The following borehole log is belonging to the site investigation of a transportation facility in Pendik district. The last case is belonging to a site investigation study of a transfer hub in the Büyükçekmece district. The details of the selected boreholes are summarized in Table 1. The soil profile of the first case consists of alluvial deposits upon clay, sand and carbonated limestone layers. The soil profile of the second case mainly consists of clay layers named Çekmece Formation (Tç). The third case consists of gravelly-sandy clay layers overlying arkosic sandstone which is known as Sultanbeyli Formation (Ts). The last case consists of clayey-gravelly sand layers overlying stiff clay layers which is a typical example of Avcilar formation. Each of the selected cases consists of soil profiles that can have effects on seismic wave propagation. In this context, they will be representative cases for areas with similar soil properties in terms of their effects on the propagation of seismic waves. The soil profiles of the determined locations were modeled using DEEPSOIL site response analysis program which is an widely used an equivalent linear and non-linear one-dimensional (1D) seismic site response analysis software. The analyses were conducted in two categories namely; i. non-linear time-domain (NL-TD) and ii. equivalent-linear frequency domain (EL-FD) site response analysis. The general quadratic/hyperbolic model $(\mathrm{GQH})$ which defines the shape of the backbone curve for stress-strain relation proposed by Groholski [13] was used in the analysis. Non-masing hysteresis models are used to reduce the size of loops and achieve similar behavior of the soil as in laboratory conditions. The soil profile was divided into different numbers of sub-layers with a thickness not exceeding $2 \mathrm{~m}$ and following lower and upper depths given in Table 2. Thus, the maximum frequency of the soil layers was provided to be greater than $30 \mathrm{~Hz}$. The empirical modulus reduction and damping curves proposed by Darendeli [14] 
were used in response analysis to represent soil behavior. The MRDF fitting procedure was applied to modulus reduction and damping curves. The shear wave velocity of the soil layers was calculated using the following empirical correlation;

$\mathrm{V}_{\mathrm{s}}=51.5 \mathrm{~N} 0.516$

where $\mathrm{N}$ is the blow number of SPT test [15]. The lithology and soil properties of the selected cases are given in Table 2. Simulations were carried out by using Kozlu station records of the 1999 Kocaeli Earthquake. The acceleration time history of the motion employed in the numerical analysis is shown in Figure 3.

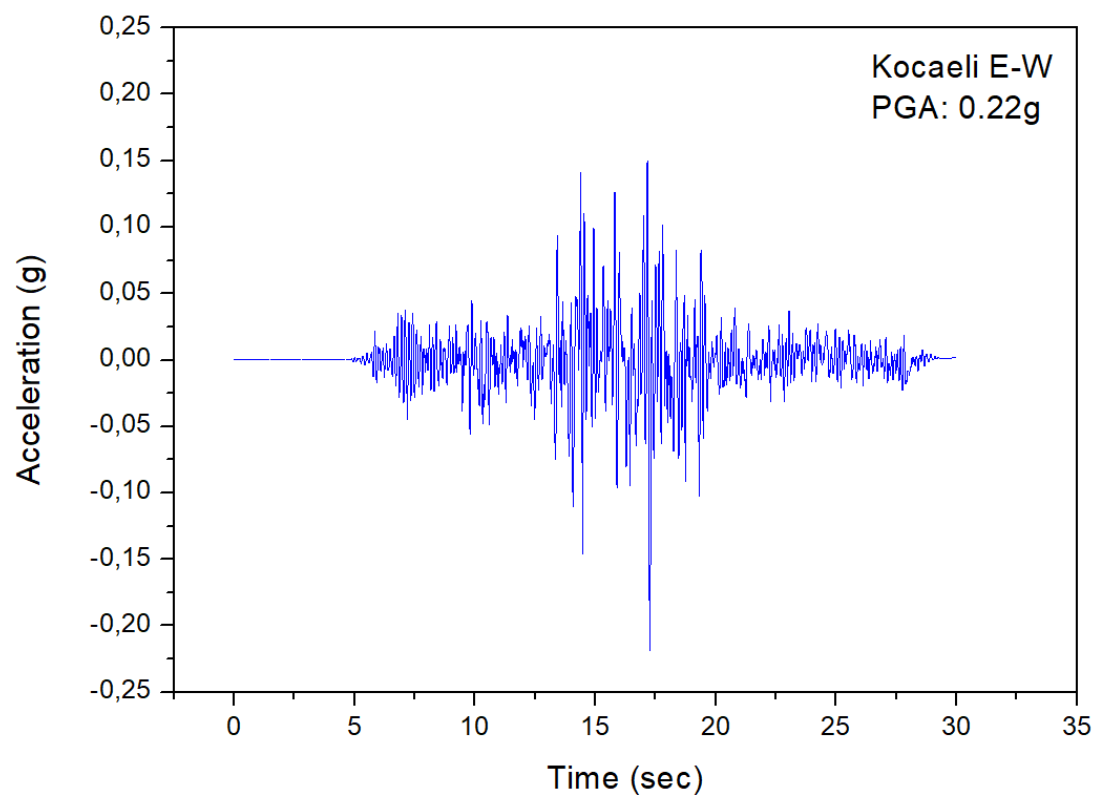

Figure 3. The acceleration time history of the 1999 Kocaeli EW earthquake

Table 1. The location and depth details of the boreholes

\begin{tabular}{|c|c|c|c|c|c|c|}
\hline Case & \multirow{2}{*}{ Borehole } & District & \multicolumn{2}{|c|}{ Coordinates } & \multirow{2}{*}{$\begin{array}{c}\text { Final Depth } \\
\text { (m) }\end{array}$} & $\begin{array}{c}\text { GWT } \\
\text { (m) }\end{array}$ \\
\cline { 3 - 6 } & & & X & y & 42 & 2 \\
\hline Case I & BHI & Şile & 486667 & 4555680 & 25 & 19.60 \\
\hline Case II & BHII & Avcılar & 392662 & 4540042 & 30 & 14.60 \\
\hline Case III & BHIII & Pendik & 443169 & 4529686 & & 16 \\
\hline Case IV & BHIV & B.çekmece & 384294 & 4544018 & 40 & \\
\hline
\end{tabular}


Table 2. The lithology and soil properties of selected cases

\begin{tabular}{|c|c|c|c|c|c|c|c|c|}
\hline Borehole & $\begin{array}{c}\text { Depth } \\
\text { (m) }\end{array}$ & Lithology & $\begin{array}{c}\mathbf{c} \\
\mathbf{k P a})\end{array}$ & $\begin{array}{l}\phi \\
\left({ }^{\circ}\right)\end{array}$ & $\begin{array}{c}\gamma \\
\left(\mathbf{k N} / \mathbf{m}^{3}\right)\end{array}$ & $\begin{array}{c}\text { PI } \\
(\%)\end{array}$ & $\begin{array}{c}\text { SPT- } \\
N_{\text {avg }}\end{array}$ & $\begin{array}{c}\mathbf{V}_{\mathrm{s}} \\
(\mathrm{m} / \mathrm{sec})\end{array}$ \\
\hline \multirow{4}{*}{ BHI } & $0-1.5$ & Artificial fill & 0 & 25 & 17 & - & - & 100 \\
\hline & $1.5-9$ & Medium clay & 46 & 8 & 18 & $20.6-38.2$ & 10 & 169 \\
\hline & $9-37.5$ & Medium sand & 0 & 30 & 18 & - & 13 & 193 \\
\hline & $37.5-42$ & Limestone & 150 & 38 & 24 & - & $\mathrm{R}$ & 390 \\
\hline \multirow[t]{3}{*}{ BHII } & $0-1.5$ & Sandy stiff clay & 0 & 22 & 17 & - & 20 & 235 \\
\hline & $1.5-7.5$ & Very stiff clay & 10 & 24 & 18 & $8-30$ & 32 & 308 \\
\hline & $7.5-25$ & Very stiff-hard clay & 18 & 27 & 19 & $32-34$ & 60 & 426 \\
\hline \multirow[t]{3}{*}{ ВHIII } & $0-15.35$ & Artificial fill & 0 & 24 & 17 & - & - & 100 \\
\hline & $15.35-20$ & Gravelly sandy clay & 0 & 27 & 19 & - & 12 & 178 \\
\hline & $20-50$ & Gravelly sandy clay & 10 & 29 & 19 & 15 & 45 & 367 \\
\hline \multirow[t]{3}{*}{ BHIV } & $0-1.5$ & $\begin{array}{l}\text { Fill, angular gravel, } \\
\text { sand, clay }\end{array}$ & 0 & 24 & 17 & - & $35-\mathrm{R}$ & 323 \\
\hline & $1.5-8$ & Clayey gravelly sand & 0 & 33 & 19 & - & 50 & 388 \\
\hline & $8-21$ & Very stiff-hard clay & 30 & 28 & 20 & $27-36$ & 55 & 407 \\
\hline
\end{tabular}

\section{RESULTS AND DISCUSSION}

\subsection{Non-linear Analysis}

Under the applied seismic motion, the general soil profile responses are evaluated by means of Peak Ground Acceleration (PGA) and acceleration response spectra with 5\% damping. The NLA site response analysis under the 1999 Kocaeli Earthquake was performed and the variations of site response spectra for the selected boreholes are given in Figure 4. The upper layers of BHI and BHIII borehole logs having lower shear wave velocities displayed an amplification effect on applied earthquake motion. However, the lower layers with higher SPT$\mathrm{N}$ values and shear wave velocities deamplified the applied motion. The soil layers represented by BHII and BHIV borehole logs deamplified the applied motion. It was observed that relatively soft and loose artificial fill layers of soil profiles displayed an amplification effect, while deamplification effect in varying degrees was observed by stiff clay or dense sand layers. Even it is classified as a fill layer, the top layer of the BHIV borehole log having relatively higher SPT-N and shear values displayed better performance than a typical uncontrolled filling layer. The variation of PGA and displacement values with the depth of soil profiles for NLA can be seen in Figure 5. PGA values are measured with reference to the top of the related soil layer. The PGA of the applied ground motion is $0.22 \mathrm{~g}$. The upper layers of BHI and BHIII borehole logs amplified the PGA up to $0.32 \mathrm{~g}$ and $0.27 \mathrm{~g}$, respectively. Considering the PGA $0.22 \mathrm{~g}$ input motion, the increase in acceleration is calculated as $45 \%$ and $23 \%$, respectively. The lower layers of those profiles and all layers of BHII and BHIV borehole logs displayed deamplification of seismic waves. The maximum deamplification is observed as $78 \%$ by the lowest layer of BHIV which mainly consists of very stiff hard clay layers. The highest lateral displacement was calculated by BHII as $14 \mathrm{~mm}$ so that it is almost constant along with the depth of profile.

\subsection{Equivalent Linear Analysis}

The variation of acceleration response spectra with 5\% damping for ELA is represented in Figure 6 . The highest acceleration values are obtained by top layers of BHI, BHIII and BHIV as $1.3 \mathrm{~g}, 1.4 \mathrm{~g}$ and $0.8 \mathrm{~g}$, respectively. These results of the ELA analysis indicate a considerable change in the characteristics of seismic incident waves by amplifying them at surface layers. 
However, lower layers of those boreholes consisting of very stiff clay layers deamplified the applied motion. The soil layers of the BHII borehole log consists of stiff clay layers that deamplified the acceleration of the input motion down to $0.4 \mathrm{~g}$. The variation of PGA and displacement values with the depth of soil profiles for ELA can be seen in Figure 7. Remembering the PGA of the input motion is $0.22 \mathrm{~g}$, the PGA values calculated at surface layers of the soil profiles of BHI, BHII and BHIV borehole logs are lower than of the applied input motion. The deamplification observed by BHII borehole log is attributed to the stiff clay layers. The displacements calculated by BHII and BHIV borehole logs are observed to have the highest values at the surface as $22 \mathrm{~mm}$ and $20 \mathrm{~mm}$, respectively. In contrast to the measured acceleration values, it was observed that the maximum displacement values obtained along the depth of the soil profiles were varied within a limited range for each of the investigated boreholes.

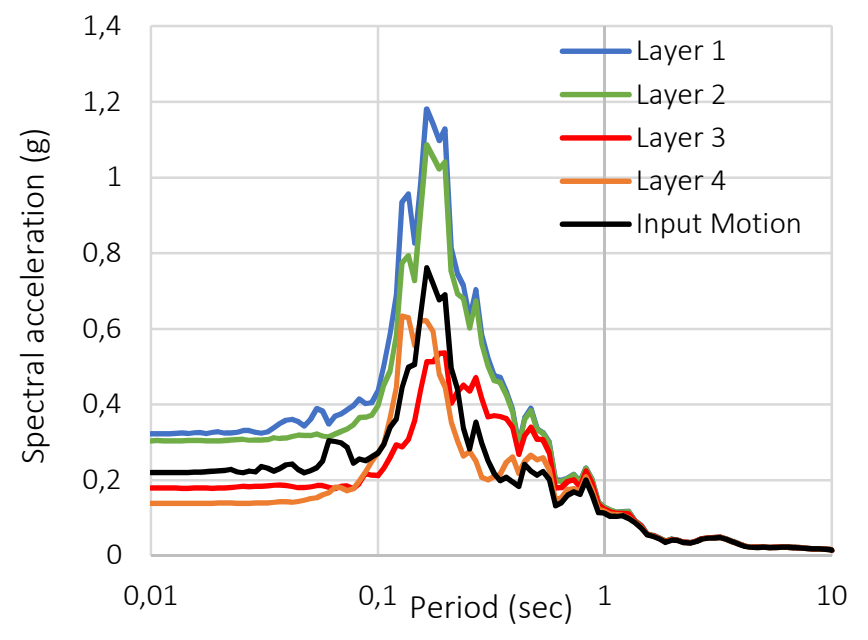

(a)

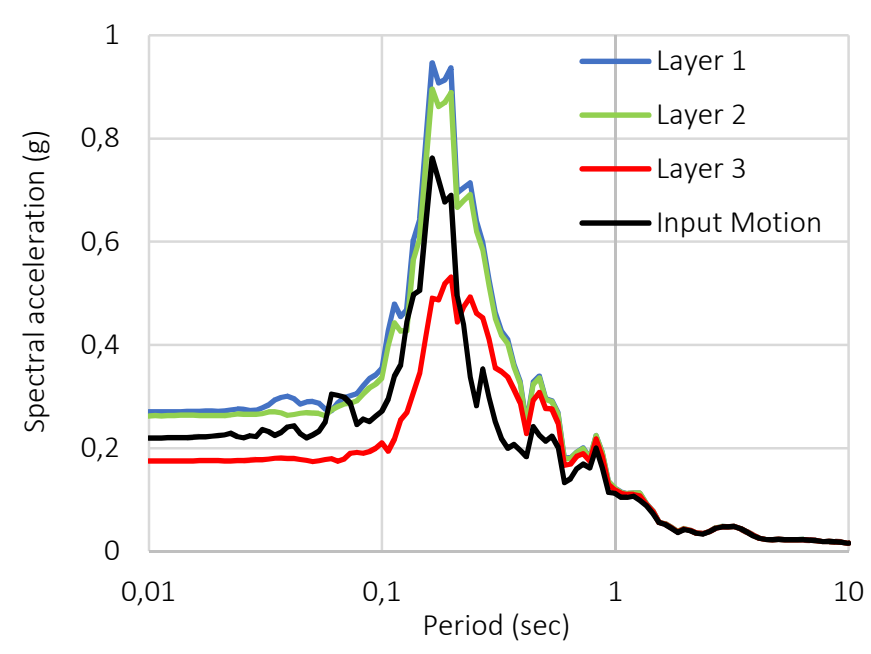

(c)

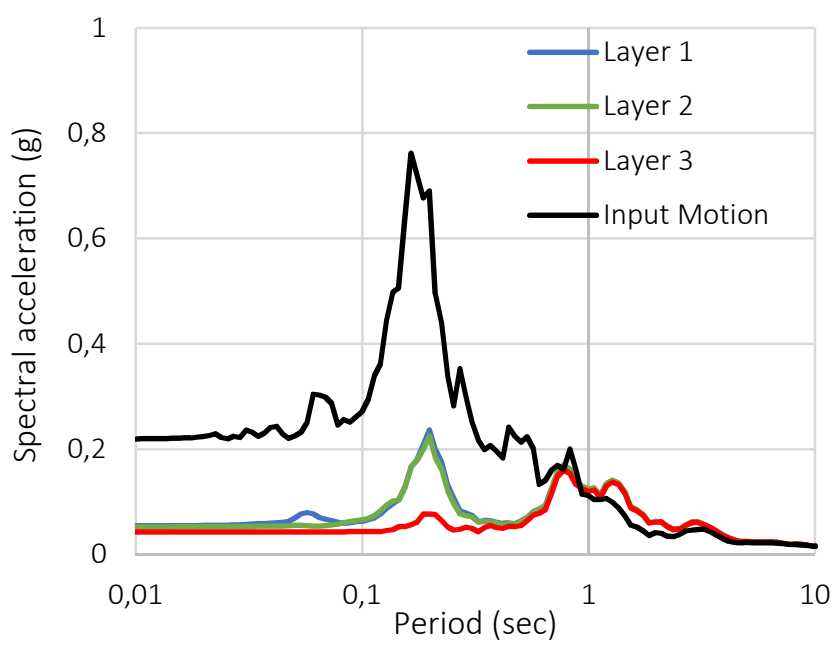

(b)

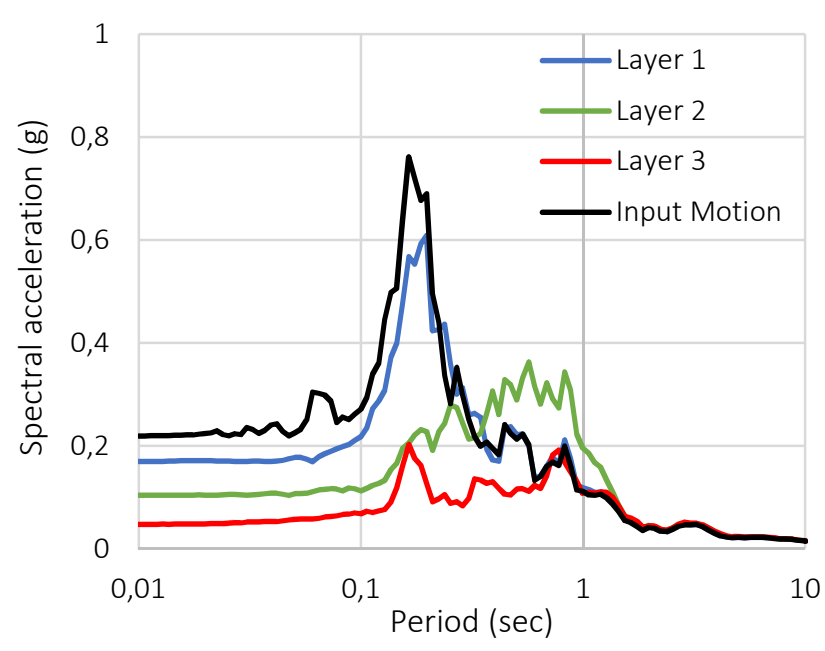

(d)

Figure 4. Site response spectra for a.BHI, b.BHII, c.BHIII and d.BHIV under Kocaeli Earthquake (NLA) 

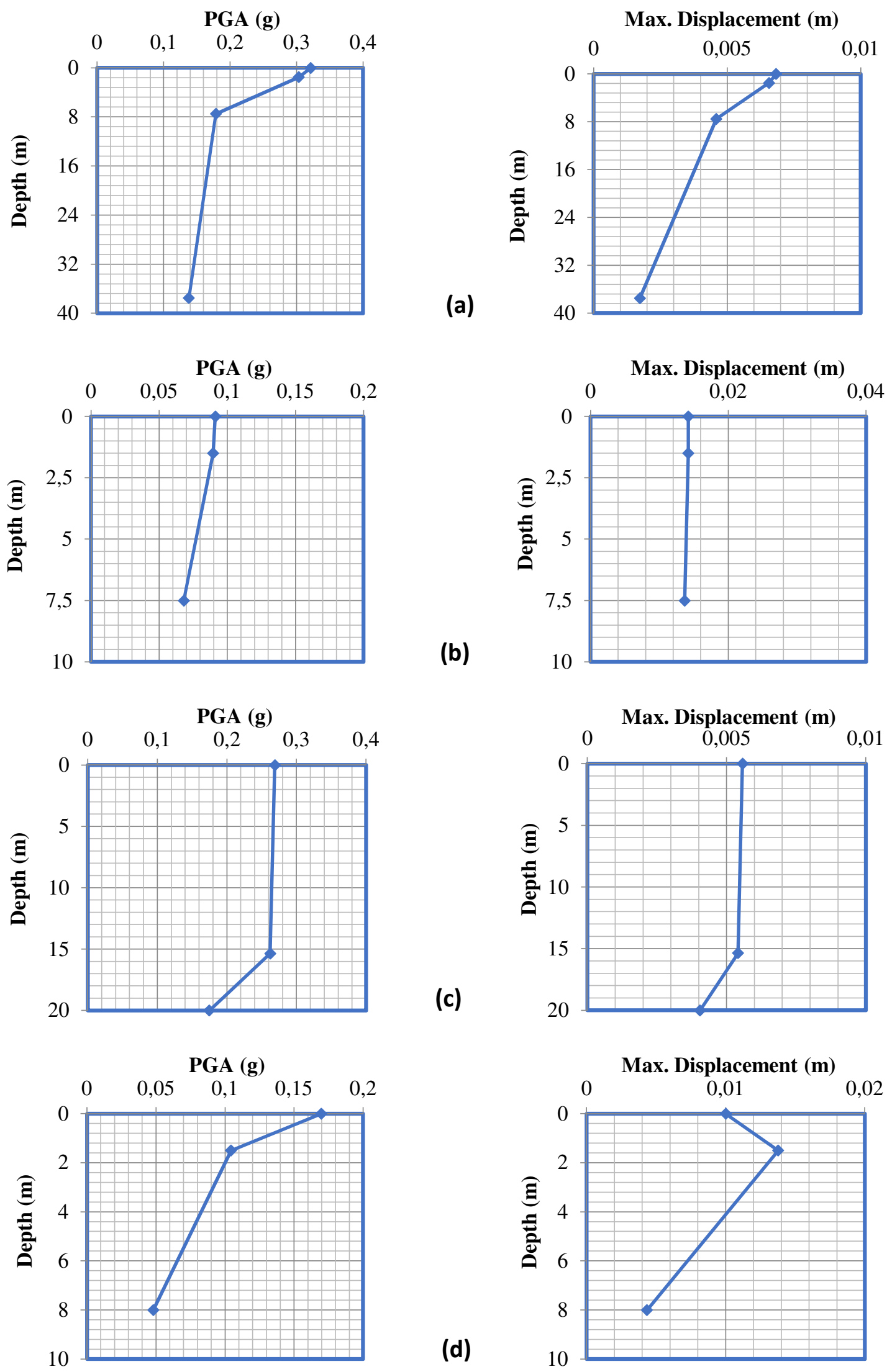

Figure 5. The variation of PGA values and maximum displacement with depth for a.BHI, b.BHII, c.BHIII and d.BHIV under Kocaeli Earthquake (NLA) 


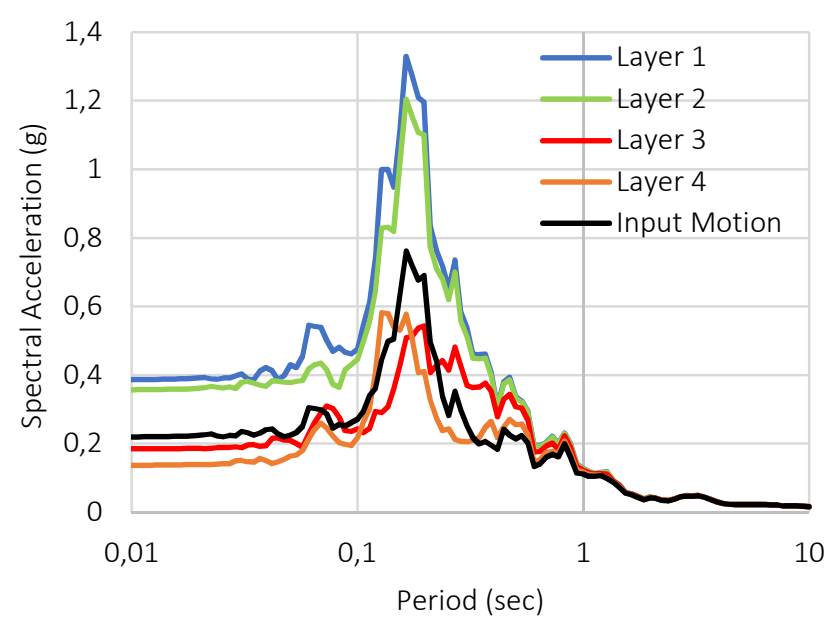

(a)

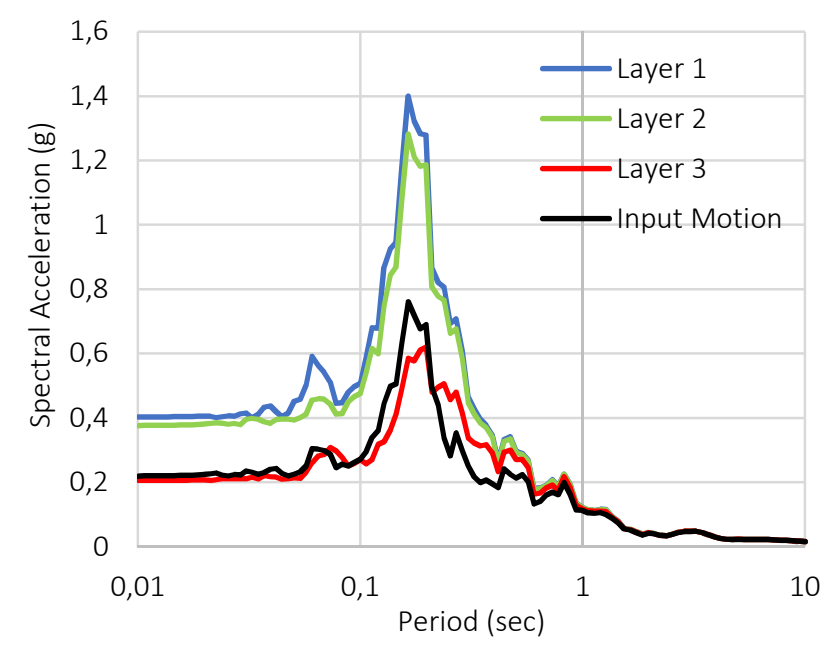

(c)

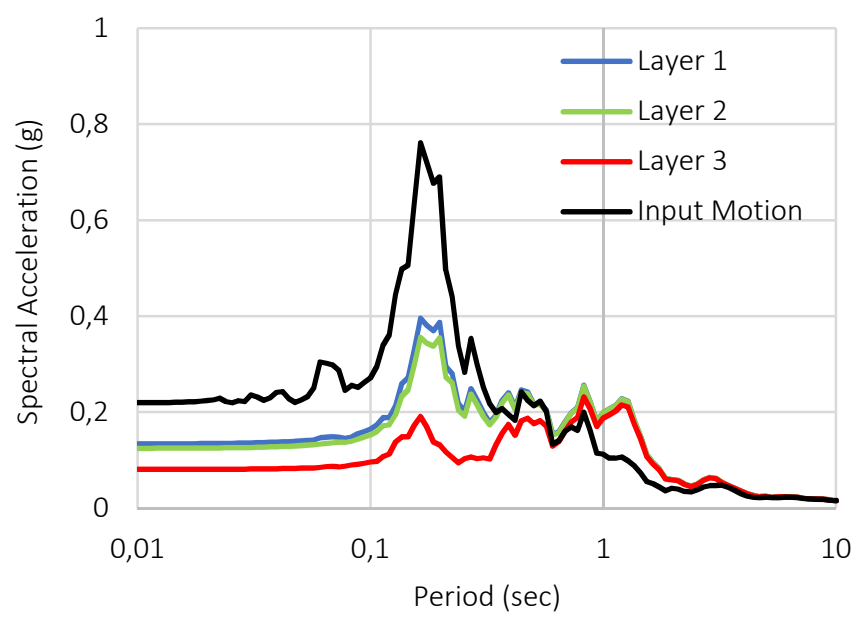

(b)

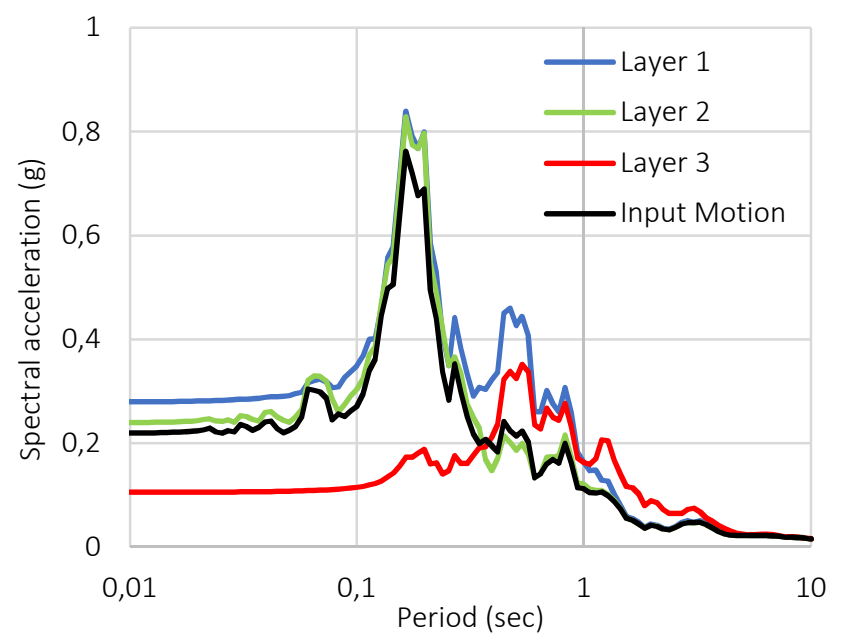

(d)

Figure 6. Site response spectra for a.BHI, b.BHII, c.BHIII and d.BHIV under Kocaeli Earthquake (ELA)

The results of the analyses are summarized in Table 3. The results obtained by both NLA and ELA demonstrate that the upper layers of the BHI and BHIII borehole logs amplified the accelerations, while the lower layers deamplified the seismic motion. There is a decrease of $45 \%$ and $22 \%$ in PGA values of BHI and BHIII obtained by NLA, respectively. The maximum deamplification observed by the lowest layer of BHII and BHIV borehole logs as $69 \%$ and 78 $\%$, respectively. Considering the results of ELA, the seismic waves are amplified as $73 \%$ and $81 \%$ at surface layers of BHI and BHIII, respectively. The deamplification ratios observed by the BHIII borehole log from the lowest layer to the surface layer are $61 \%, 43 \%$ and $40 \%$ respectively. Inconsistent with the literature studies, the soil response of ELA using the total stress method demonstrates higher PGA values than of NLA which based on the effective stress method. This is due to the linear nature of ELA using only a single value of stiffness and damping for the entire duration of the ground motion. This over-predicted stiffness and underpredicted damping for shear strain greater than the effective shear strain leads to higher PGA values. Although it is known that ELA lacks the ability to exhibit the non-linear behavior of soils under seismic loading, it is widely used in literature studies with NLA due to its easy application. It was observed that the calculated maximum displacement values obtained by both approaches are very close to each other for all cases. 

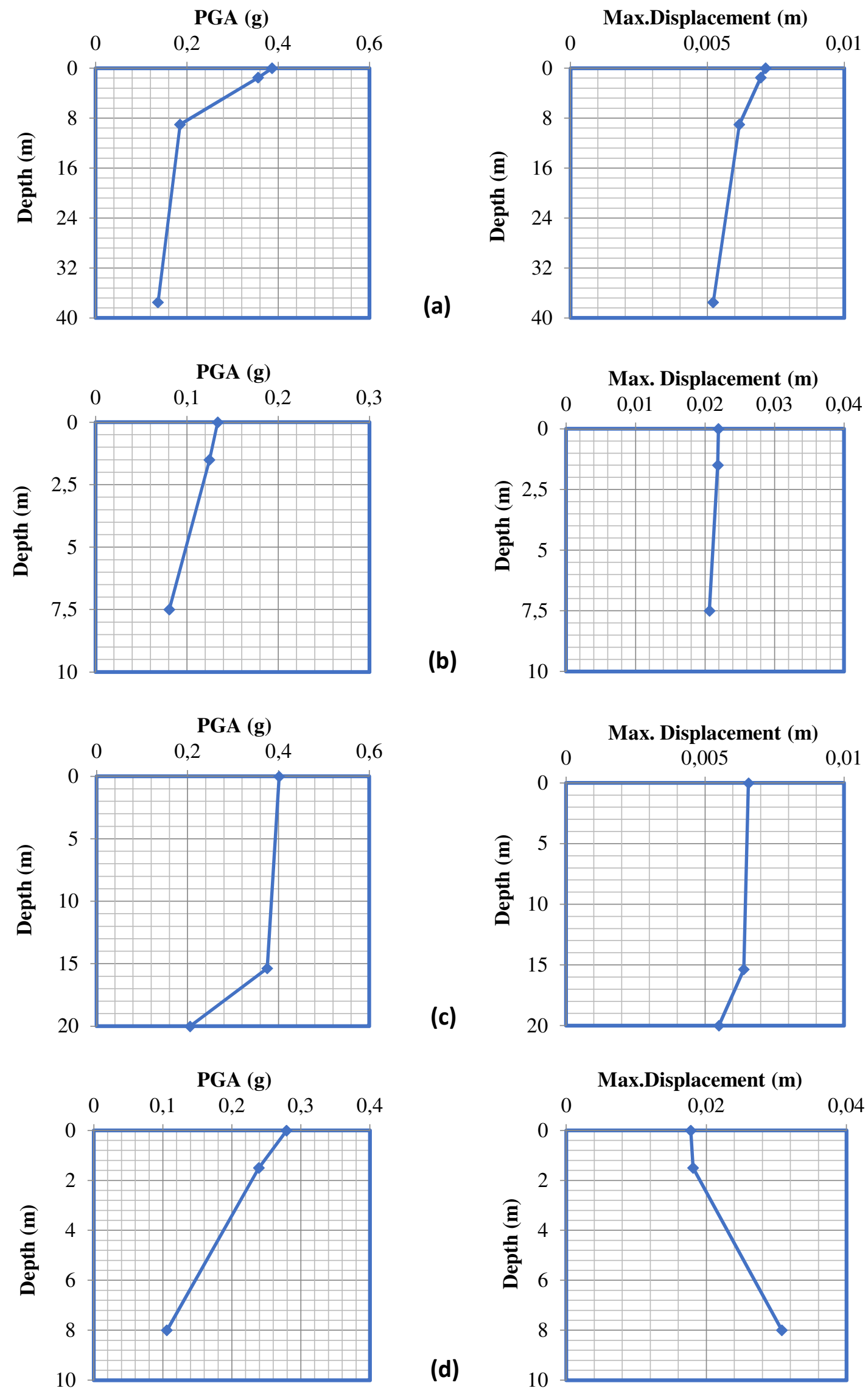

Figure 7. The variation of PGA values and maximum displacement with depth for a.BHI, b.BHII, c.BHIII and d.BHIV under Kocaeli Earthquake (ELA) 
Table 3. Summary of the analysis results

\begin{tabular}{|c|c|c|c|c|c|c|}
\hline \multirow[b]{2}{*}{ Borehole } & \multicolumn{3}{|c|}{ NLA } & \multicolumn{3}{|c|}{ ELA } \\
\hline & $\begin{array}{c}\text { PGA } \\
\text { (g) }\end{array}$ & $\begin{array}{c}\text { Difference } \\
(\%)\end{array}$ & $\begin{array}{c}\text { Displacement } \\
\text { (m) }\end{array}$ & $\begin{array}{c}\text { PGA } \\
\text { (g) }\end{array}$ & $\begin{array}{c}\text { Difference } \\
(\%)\end{array}$ & $\begin{array}{c}\text { Displacement } \\
\text { (m) }\end{array}$ \\
\hline \multirow{4}{*}{ BHI } & 0,321078 & $45 \%$ & 0,006826 & 0,386095 & $73 \%$ & 0,007120 \\
\hline & 0,303349 & $36 \%$ 수 & 0,006559 & 0,355740 & $64 \%$ & 0,006943 \\
\hline & 0,178422 & $19 \% \downarrow$ & 0,004586 & 0,184802 & $16 \% \downarrow$ & 0,006161 \\
\hline & 0,137776 & $37 \%$ & 0,001726 & 0,136516 & $38 \% \downarrow$ & 0,005206 \\
\hline \multirow{3}{*}{ BHII } & 0,091161 & $59 \% \downarrow$ & 0,014195 & 0,133641 & $40 \% \downarrow$ & 0,021923 \\
\hline & 0,089528 & $60 \% \downarrow$ & 0,014181 & 0,124590 & $43 \% \downarrow$ & 0,021836 \\
\hline & 0,067955 & $69 \% \downarrow$ & 0,013662 & 0,080556 & $61 \% \downarrow$ & 0,020628 \\
\hline \multirow{3}{*}{ BHIII } & 0,268959 & $22 \%$ ㅅ & 0,005571 & 0,401524 & $81 \%$ & 0,006562 \\
\hline & 0,262159 & $19 \%$ & 0,005410 & 0,375257 & $68 \%$ & 0,006392 \\
\hline & 0,174588 & $21 \% \Downarrow$ & 0,004041 & 0,205297 & $9 \% \downarrow \downarrow$ & 0,005492 \\
\hline \multirow{3}{*}{ BHIV } & 0,169559 & $23 \% \downarrow$ & 0,009995 & 0,279067 & $27 \%$ & 0,017765 \\
\hline & 0,104224 & $53 \% \downarrow$ & 0,013772 & 0,238967 & $9 \% \quad \hat{\uparrow}$ & 0,018100 \\
\hline & 0,047910 & $78 \% \downarrow$ & 0,004337 & 0,105624 & $50 \% \downarrow$ & 0,030765 \\
\hline
\end{tabular}

* The red arrow reflects the amplification in PGA. The green arrow reflects the deamplification in PGA.

The difference in PGA is calculated with respect to the input motion with PGA: $0.22 \mathrm{~g}$.

\subsection{Liquefaction Analysis}

In site response analysis studies, another issue that is as important as the effects of soils on the propagation of earthquake waves is the evaluation of the liquefaction potential of the soil under dynamic loadings. It is stated that the soil deposits with clay content may be evaluated as nonliquefiable [16]. It is indicated that soils having a liquid limit (LL) and the plasticity index (PI) lower than $30 \%$ and $10 \%$ respectively, are prone to liquefaction. The soils may liquefy if all of the following conditions are met; i. percent less than $5 \mathrm{~mm}<15 \%$, ii. LL $<35$, iii. water content, $\mathrm{Wn}>0.9 * \mathrm{LL}[17]$. The soil profiles mostly have LL higher than $35 \%$. The natural water content of the tested specimens from the different depths of boreholes is below the limit values. Except for Case I, each of the investigated cases containing a considerably high amount of finer content of the soil. The plasticity index of the tested samples is well above $10 \%$. The measured GWT of Case II, III and IV are varied between 14.60 to $19.60 \mathrm{~m}$. Since the location of BHI is close to the river, the GWT is measured as $2 \mathrm{~m}$. However, considering all of the liquefaction susceptibility criteria for the investigated soil profiles, it is concluded that the examined soil profiles have no liquefaction potential (Table 4).

Table 4. Summary of the liquefaction evaluation of the soil profiles

\begin{tabular}{|l|c|c|c|c|}
\hline Criteria & Case I & Case II & Case III & Case IV \\
\hline $\mathbf{L L}<\mathbf{3 5} \%$ & NP & $62.3 \%$ & $29-46 \%$ & $57.9 \%$ \\
\hline $\mathbf{W}_{\mathbf{n}}>\mathbf{0 . 9}$ *LL & NP & $31.3 \%$ & $8.6-24.8 \%$ & $27.6 \%$ \\
\hline Percent finer than $\mathbf{0 . 0 0 5} \mathbf{~ m m}<\mathbf{1 5 \%}$ & $4.3 \%$ & $96.3 \%$ & $30-94 \%$ & $62.7 \%$ \\
\hline PI $<\mathbf{1 0 \%}$ & NP & $34.3 \%$ & $10-21.2 \%$ & $32.9 \%$ \\
\hline GWT $<\mathbf{1 0} \mathbf{m}$ & 2 & 19.60 & 14.60 & 16 \\
\hline
\end{tabular}




\section{CONCLUSION}

In this study, apart from rock units such as greywackes and limestone, the effects of soil conditions within the local geology of Istanbul on the propagation of seismic waves were investigated. 1D site response analyzes were carried out using real earthquake data with two different approaches namely; i. equivalent linear analysis, ii. non-linear analysis. The following conclusions have been drawn from the analysis conducted:

- The amplification of acceleration was observed by BHI and BHIII borehole logs (Layer 1 and 2). The observed amplification effect is attributed to the loose state of the upper layers. The deamplification of seismic waves observed by BHII and BHIV borehole logs is explained with the relatively dense and stiff layers.

- The non-linear analysis approach leads to lower PGA and spectral acceleration values compared to the equivalent linear analysis. This is due to over-predicted stiffness and underpredicted damping for shear strains greater than the effective shear strain.

- Since the liquefaction criteria are not met, the analyzed soil profiles do not pose a liquefaction risk even some of them are individually met by Case I.

- The behavior of the investigated soil units can also represent the behavior of soil profiles with similar characteristics in different regions.

The soil profiles for which seismic site response analyzes are performed belong to a large metropolis area. Therefore, it is not possible to model the entire area with a limited number of analyzes. However, the investigated soil profiles are typical soil formations encountered in various regions of Istanbul. In this sense, selected representative cases are important in predicting the behavior of areas with similar soil properties. It should also be stated that the amount of amplification and deamplification will vary with the input motion used.

Acknowledgement: The author would like to thank "DS-Mersa Proje Uluslararası Müh. ve Müss. Ltd. Şti." for their support.

\section{REFERENCES}

[1] Tezcan, S. S. and İpek, M. (1973). Long Distance Effects of the March 28, 1970 Gediz Turkey Earthquake, Earthquake Engineering and Structural Dynamics, 1, 203- 215.

[2] Hashash, Y.M.A., Phillipes, C. and Groholski, D. (2010). Recent Advances in Non-linear site response analysis, 5th International Conference on Recent Advances in Geotechnical Earthquake Engineering and Soil Dynamics, San Diego, California, 1-21.

[3] Seed, H.B. and Idriss, I.M. (1969). Influence of soil conditions on ground motions during earthquakes, Journal of the Soil Mechanics and Foundation Division (ASCE), 95, 99-137.

[4] Idriss, I.M. and Sun, J.I. (1992). Shake91: A computer program for conducting equivalent linear seismic response analysis of horizontally layered soil deposits. User's Guide, Center for Geotechnical Modeling, Civil Engineering Department, UC Davis.

[5] Schnabel, P.B., Lysmer, J. and Seed, H.B. (1972). SHAKE-A computer program for earthquake analysis of horizontally layered sites, Earthquake Engineering Research Center, University of California, Berkeley, Report No. EERC 72-12.

[6] Park, D. and Hashash, Y.M.A. (2004). Soil damping formulation in nonlinear time domain site response analysis, Journal of Earthquake Engineering, 8(2), 249:274. 
[7] Hashash, Y.M.A., Dashti, S., Romero, M.I., Ghayoomi, M., and Musgrove, M. (2015). Evaluation of 1-D seismic site response modeling of sand using centrifuge experiments, Soil Dynamics and Earthquake Engineering, 78, 19-31.

[8] Hashash, Y.M.A. and Park, D. (2001). Non-linear one-dimensional seismic ground motion propagation in the Mississippi embayment, Engineering Geology, 62(1-3), 185-206.

[9] Park, D.and Hashash, Y.M.A. (2008). Rate-dependent soil behavior in seismic site response analysis, Canadian Geotechnical Journal, 45(4), 454-469.

[10] Edinçliler, A. and Calikoglu, M. (2016). Comparison of Site Response of Unimproved and Improved Soils Using DEEPSOIL, 12th International Congress on Advances in Civil Engineering, ACE 2016, Bogazici University, Istanbul, Turkey.

[11] Edinçliler, A. and Tuncay, G.S. (2018). Nonlinear and Equivalent Linear Site Response Analysis for the Bodrum Region, Eurasian Journal of Civil Engineering and Architecture, 2 (2), 59-68.

[12] Yıldırım, M., Tonaroğlu, M., Selçuk, M.E. and Akgüner, C. (2013). Revised stratigraphy of the tertiary deposits of Istanbul and their engineering properties, Bulletin of Engineering Geology and the Environment, 72(3-4), 413-420.

[13] Groholski, D.R., Hashash, Y.M.A., Kim, B., Musgrove, M., Harmon, J. and Stewart, J.P. (2016). Simplified Model for Small-Strain Nonlinearity and Strength in 1D Seismic Site Response Analysis, Geotech. Geoenviron. Eng., ASCE 142, 9.

[14] Darendeli, M.B. (2001). Development of a new family of normalized modulus reduction and material damping curves, Ph.D. dissertation, University of Texas at Austin.

[15] İyisan, R. (1996). Correlations between shear wave velocity and in-situ penetration test results, Tech. J. Chamber Civil Eng. Turkey, 7, 1187-99 (in Turkish).

[16] Youd, T.L., Idriss, I.M., Andrus, R.D., Arango, I., Castro, G., Christian, J.T., Dobry, R., Finn, L.W.D.,. Harder, L.F Jr, Hynes, M.E., Ishihara, K.J.P., Koester, S.S.C. Liao, W.F. Marcuson III, G.R. Martin, J.K. Mitchell, Y. Moriwaki, M.S. Power, P.K. Robertson, H.B. Seed, K.H. Stokoe. (2001). Liquefaction Resistance of Soils: Summary Report from the 1996 NCEER and 1998 NCEER/NSF Workshops on Evaluation of Liquefaction Resistance of Soils, JGGE, 127(10).

[17] Seed, H.B. and Idriss, I.M. (1982). Ground motions and soil liquefaction during earthquakes, EERI Monograph, Berkeley, CA. 